\title{
Thoroughly Exploring the Mode of Training Higher Vocational Talents under the Modern Apprenticeship System_-Taking the Chain Management Major as an Example
}

\author{
Li Lan \\ Logistics Engineering and Management Faculty, Kunming Metallurgy College, Kunming, China
}

Keywords: modern apprenticeship, chain management, talent training, school-enterprise cooperation

\begin{abstract}
As an important means of talent training in the industry, the chain management specialty is different from other professional disciplines and pays more attention to the twoway training of management basic theories and applied skills. In the context of the new era, if the professional curriculum is to fundamentally realize the strengthening of students' practical skills and the realization of students' "zero distance" employment aspirations, it is necessary to actively construct a talent cultivation mechanism that combines schoolenterprise cooperation and work, while modern apprentices In this context, the system has emerged as the times require, and the goal of training talents in higher vocational colleges is to achieve, providing system and structural support. Based on the comprehensive analysis of the modern apprenticeship system, the article deeply analyzes the main problems existing in the current chain management professional talent training mode, and reconstructs the modern education undertaking through the combination with the actual development of the colleges and universities. The development of professional talent training mode, and effectively promote the overall improvement of the quality of professional personnel training.
\end{abstract}

\section{The Connotation and Characteristics of a Modern Apprenticeship System}

\subsection{The connotation of modern apprenticeship}

The formation of the "modern apprenticeship" concept can be traced back to the end of the 1980s. It provides a reliable reference for the establishment of modern talent training systems in various countries and regions of the world, and through the integration with different national characteristics, the formation of independence Distinctive modern apprenticeship models, such as the British "modern apprenticeship", Germany's "dual system", the United States' "cooperative learning system", Australia's "new apprenticeship" and so on. In 2014, China's national education department first proposed a new model aimed at deepening the integration of production and education, schoolenterprise cooperation, and the cultivation of innovative technical skills. Different from the traditional apprenticeship training, the main body of the modern apprenticeship system is changed from the 
school to the education mode supported by the school and the enterprise. It is strictly in accordance with the mode of on-the-job training and off-the-job learning. Students can move from the traditional teaching mode to the society to the enterprise master. The leadership of learning to learn the corresponding practical operation skills of the West, while improving the students' practical ability to connect with the theory, can also achieve the purpose of consolidating theoretical knowledge.

\subsection{Characteristics of Modern Apprenticeship}

The first is to implement the dual-sports sportsman, adding the enterprise education function on the basis of the traditional school education; the second is to upgrade the education tutor to the "double-type" education mode, and the enterprise master and the school teacher jointly have the knowledge and The obligation and responsibility of skills; the third is to implement a dual assessment mechanism, the school is mainly responsible for the assessment of students' professional basic theories, the enterprise has the right to supervise the students' vocational skills, and if you want to become a true apprentice, you need to get the school and The enterprise jointly recognizes the professional qualification certificate; the fourth is to pay attention to the training of students' basic ability and vocational skills in the short term, and pay more attention to the improvement of students' post-transfer ability and long-term sustainable development ability.

\section{The Necessity of Implementing Modern Apprenticeship in Modern Higher Vocational Colleges}

On the one hand, it is conducive to promoting employment. For a country, the level of economic and social productivity depends to some extent on the overall employment level of the country, and college students are the main force of the employment team, especially the vocational education institutions with oriented training. The level of the situation will directly affect the overall employment rate of the entire college student social group. The students who have been trained by the modern apprenticeship system have absolute advantages in the basic ability of the post, and the students have already obtained relevant professional assessments, and have already been affirmed. After graduation, they can adapt to the post requirements within a short period of time. The various tasks have the ability to complete on their own, and such graduates are very popular in the enterprise, which helps the students to solve the employment problem to some extent.

On the other hand, it is conducive to solving the problem of difficulty in recruiting enterprises. Over the past 40 years of reform and opening up, the domestic economy has maintained a high-speed and stable development trend, which has led to an increasing demand for labor in various industries. As a country with an aging phenomenon that is extremely common, the labor available for production is seriously insufficient. For some enterprises, due to the particularity of their own industry types, the characteristics of high intensity, zero technology and low salary in actual production projects have virtually increased the difficulty for enterprises in recruiting. Through the investigation and research on the actual development status of the retail industry, it is found that the demand for multiprofessional talents in China's retail industry can reach about 10 million in the next few years, but from the graduation of professional talents in each college, it can meet the retail industry. There are only about 4 million people in employment standards, and there is a huge gap in professional talents, and the situation will continue to intensify in the future. If the modern apprenticeship training model is introduced in time for the chain management professional, it will not only make up for the labor shortage in the modern retail industry, but also reserve some talents for the subsequent development of the enterprise. 


\section{The main problems in the training mode of professional talents in chain management}

\subsection{Lack of Clear Talent Training Goals}

At present, the relevant professional academic research fields use the "technical application type" approach to position higher vocational education. However, from the actual investigation, the colleges and universities in the chain management professional courses are developed according to the type of school. The talent training goals are also different. "High-quality skilled talents", "highquality technical skills talents", "high-skilled application-specific talents" are all the goals set by the institutions. In general, the orientation of the college's talent training objectives is unified at two levels, namely the design level and the operational level, which are two very common forms at this stage. For example, Zhejiang practice-oriented colleges and universities develop common talent training goals through cooperation with enterprises. However, whether such talent training objectives can be adapted to the implementation of modern apprenticeships in colleges and universities remains to be considered. In the case of factors such as the difference in targeting, it is highly likely that the institutions will have a huge difference in the quality of personnel training.

\subsection{The Content of the Course Lacks Effective Vocational Ability Training}

According to relevant investigations and studies, at present, the major content and composition of major universities offering chain management courses are mainly composed of social basic quality courses, professional compulsory courses and professional elective courses. Under the background of the new curriculum reform, the cultivation of modern apprenticeship talents not only requires students to have a solid theoretical foundation, but also emphasizes the students' post-practice ability. Therefore, in the course of curriculum setting, they insist on mutual connection with professional positions. However, from the current actual situation, most colleges and universities in the setting of teaching content, completely out of the actual job needs of retail enterprises, although students have received skills learning and training related to the actual position in the early stage, but after entering the real job position It is necessary to combine the actual situation and needs of the post to improve and optimize the skills. It is not only easy to cause great waste of personal time and energy, but also not conducive to the improvement of students' practical skills. Adapting within a short period of time, there is not enough ability to complete work tasks with high efficiency, high quality and high standards. The recognition of the performance of the company in its actual work is not high, which seriously hinders the further expansion of students' professional ability and future. Continue to develop.

\subsection{Lack of Standardization in the Talent Training Process}

From the perspective of the whole process of personnel training, the chain management profession has obvious dynamic characteristics in the actual training process. The teachers of traditional teaching activities account for the main body of the classroom. Students are often in a passive form in the learning attitude and the execution of learning tasks, which makes it difficult to fully Give play to students' creativity and initiative. At the same time, due to the unevenness of teachers' length of service, length of teaching, teaching experience and ability, and not good at making progress, it is impossible to grasp the latest knowledge and teaching standards in time, it is easy to cause students to teach and teach different teachers and masters. Under the training, the theoretical knowledge and practical skills gained are not the same. However, although some schools have formulated a series of "high standards and strict requirements" process guidelines in the actual personnel training process, they are subject to the shortage of teaching resources, such as the lack of full-time masters and 
corporate partners, etc., leading to related courses. The opening was postponed, seriously disrupting the old plans, and it was unreasonable to make some temporary adjustments, to cultivate programs and to be truly implemented, and generally to be superficial.

\subsection{There is a Gap between the Positions of the Order Enterprises and the Expectations of the Students}

Most of the work of enterprises must start from the grassroots level. Students in higher vocational colleges do not know enough about themselves, psychological counseling is not in place, and expectations for work are very high. Many students at the grassroots level are not willing to do so, so students may not graduate. The phenomenon of order enterprises going to work has caused enterprises to face the shortage of labor, especially for grassroots employees. In this way, the school-enterprise cooperation relationship, which is relatively fragile, is seriously affected, and it is difficult for enterprises and schools to form a mechanism for continuous cooperation.

\section{The Construction of Four Chain Management Professional Talent Training Mode}

\subsection{Constructing a Curriculum System Based on Vocational Ability Training}

When constructing the relevant curriculum system around the chain management professional, we should focus on the chain retail industry, and always adhere to the improvement of student employment level and employability, strictly follow the industry workflow, and analyze each The professional skills level of professional positions, such as grassroots management positions, grassroots job positions, middle and high level management positions, core positions, etc., and form a professional basis with professional foundation, core and comprehensive skills in the process of long-term practical experience accumulation. The main curriculum system strictly follows the relevant norms and rules for improving students' professional ability, and accelerates the positive transformation of students from the traditional single training mode to the professional core and professional comprehensive ability in the process of professional basic ability training. Only students who have the above-mentioned ability can The professional ability has been continuously developed.

\subsection{Deepening the Cooperation between Schools and Enterprises}

For institutions, in the initial enrollment stage, the implementation of school-enterprise cooperation should be strengthened. The enterprises that cooperate with the school can conduct primary interviews for students entering the school, and systematically evaluate and combine students' scores to screen and accept. In the process of systematic training of professional talents, relevant experts and scholars, such as schools and enterprises, should develop an integrated teaching system of "Teaching and Doing" based on the future social practice of students and follow the relevant work processes. The business philosophy and cultural connotation of the school's cooperative enterprises are injected into the professional curriculum system to help students establish a correct professional outlook and moral outlook. During the school, the main task of the study is to master the basic theoretical knowledge and skills practice methods related to the retail industry, etc., emphasizing the connection between theory and practice, and cultivating students' coordination ability, comprehensive ability and innovation ability, etc. After the internship period, the work and learning content in the company becomes a comprehensive study and mastery of the practice process. In addition, after the students enter the assessment stage, the previous evaluation and assessment of teachers and schools cannot achieve a comprehensive test of students' comprehensive learning and practical ability. In addition to the school, students should also be added to the masters and managers 
of the enterprise. The overall performance and ability of the evaluation base is recognized. According to the goal of modern apprenticeship training, the quality of student training is comprehensively evaluated. The content of the test includes both practice and theory. The forms mainly include onsite operation, written examination and oral examination.

\subsection{Clarifying the Goal of Talent Training}

At present, the development and application of modern apprenticeships in colleges and universities across the country is mainly carried out in a pilot manner. The specific application of the chain management professional is one of many professional disciplines, and it is necessary to establish a suitable talent training. Standards, while the professional talent training program is determined, the relevant systems and standards for the course development should be carefully designed to continuously enhance the coordination of the two courses of theory and practice, and cooperate with each other to actively build a work that matches the actual learning situation. Content, in order to ensure the uniformity of the final learning effect of students, we should also avoid the differences in teaching methods between school teachers and corporate teachers. For the cultivation of professional talents, it is necessary to systematically design and plan the entire talent cultivation process society, and strengthen the processing and management ability of various emergent events and problems in the cultivation process, so as to ensure the realization of the final training goal. In the actual development of domestic higher vocational education tasks, modern apprenticeship is a new type of talent training mode, which plays an active role in promoting students' professional skills, improving the quality of talents and optimizing the cooperation between schools and enterprises, encouraging the society. More companies and investments are actively involved in the training of professionals. At the current stage, the modern apprenticeship system is widely used in higher vocational colleges in China. It has planned an effective way to train professionals in colleges and universities. However, in general, it still faces pressure from various aspects in its implementation. The challenge requires constant research and exploration by relevant educators and business experts.

\subsection{Strengthening Practical Teaching}

The first is to guarantee the time for practical teaching. Through the application research and observation of modern apprenticeship in advanced countries in the West, it is found that in different teaching contents, such as theoretical teaching and practical teaching, the time and energy involved are different, generally according to the mode of $3: 7$ or $2: 8$. Carry out. Due to the difference between domestic education and Western education, the relevant departments of the state have a 4:6 model in the distribution of two different teaching tasks, $40 \%$ of which are practical courses and $60 \%$ are theoretical courses.

The second is to have a modern master education team. Introduce the modern apprenticeship system into the talent training mode of higher vocational colleges, and the whole practice teaching process requires a professional modern master. For the teachers of the chain management and management profession, they should constantly enhance their professional level and ability from their own perspective. Teachers should not have the ability to perform their research duties, but also have certain scientific research capabilities and technological development capabilities. In addition, from the perspective of the entire industry of the retail industry, its main task is to promote the accumulation of students' practical experience and the improvement of skills. The relevant experts of the enterprise should cooperate with the professional teachers of the school to create a practical and theoretical. The education team, the two sides learn together and communicate together, and fundamentally realize the overall improvement of their own quality and ability.

The third is to have a sound practice teaching system as a guarantee. Schools and enterprises must 
jointly develop an assessment plan for practical teaching and sign a strict apprenticeship training contract. The contract needs to specify the rights and obligations of each party.

\section{Conclusion}

At present, the modern apprenticeship system is a new type of talent training mode popular in domestic and foreign universities, which can promote the rapid improvement of students' vocational skills, enrich the total talent reserve of enterprises, and help the schools and enterprises to achieve "double harvest" in terms of benefits. In addition, the trial of the modern apprenticeship training mode not only comprehensively implements quality education for students, but also highly integrates vocational skills and professionalism, and greatly cultivates students' sense of social responsibility, innovation and practice.

\section{References}

[1] Zhiqun Zhao, Junlan Chen. The Construction of Modern Apprenticeship System-An Important Supplement to the Modern Vocational Education System[J]. Beijing Social Sciences 2014,15(01):328-329.

[2] Yun Qiu, Lian Liu. Research and Practice of "Order" Talent Training Model in Chain Management Specialty[J]. China Vocational and Technical Education, 2014, 06(26): 152-153.

[3] Diyun Meng, Zhao Fang. The Mode of Training Modern Talents in Higher Vocational Tourism Management Specialty[J]. Education and Occupation,2015,19(02):137-139.

[4] Wanyu Lu. Research on the Talent Cultivation Model of Modern Apprenticeship in Higher Vocational Education [D]. Dalian University, 2014.

[5] Jing Guan. Full Participation of Enterprises is the Premise of the Success of Modern Apprenticeship [J]. Vocational and Technical Education, 2014, 13 (33): 149-151.

[6] Guoyan Li, Fu Gai, Yu Zhu, et al. Construction and Practice of the "Double Body and One Wing" Curriculum System of Modern Apprenticeship System [J]. China Vocational and Technical Education, 2016, 03 (23): 475-478.

Lan Li,1980.10.30, Han, Longchang, Sichuan, Master, Vice Professor, Retailing. Logistics Engineering and Management Faculty, Kunming Metallurgy College, China 650032 